\title{
Vibrations and noise generated by rail vehicle disc brake
}

\author{
Drgania i halas generowane przez hamulec tarczowy \\ pojazdu szynowego
}

Jednym z niekorzystnych czynników wpływających na pogorszenie środowiska (szczególnie akustycznego), w którym przebywają ludzie, jest hałas generowany przez pojazdy mechaniczne. Zjawiska wibroakustyczne emitowane w szczególności przez układy hamulcowe uznawane są jako wysoce niepożądane. Problem drgań w hamulcach zarówno pojazdów kolejowych i samochodowych dostrzeżony został już w latach 30tych XX wieku [10]. Na początku badacze zwrócili uwage, że drgania i hałas generowany przez hamulec wynikaja z charakterystyki ciernej pary trybologicznej, uzależniając pojawienie się tego efektu od faktu, że współczynnik tarcia zmienia swoją wartość z prędkością obrotową. Twierdzono również, że współczynnik tarcia statycznego jest większy od tarcia kinetycznego. Konsekwencją drgań układu hamulcowego w połączeniu z propagacją dźwięku jest niestabilna praca układu hamulcowego objawiająca się zmiennym przebiegiem chwilowego współczynnika tarcia.

Opisane zagadnienia są wynikiem badań prowadzonych w ramach projektu finansowanego ze środków Narodowego Centrum Badań i Rozwoju (Program LIDER V, umowa $\mathrm{Nr}$ LIDER/022/359/L5/13/NCBR/2014).

\section{Wybrane modele drgań w hamulcach}

Do podstawowych elementów tarczowego układu hamulcowego należy tarcza hamulcowa, która na sztywno związana jest $\mathrm{z}$ zestawem kołowym oraz szczęka (obsada), z zamocowaną w niej okładziną cierną. Do obliczeń parametrów tarczowego układu dźwigniowego wykorzystuje się modele o różnym stopniu uproszczenia. Ze względu na zastosowanie modeli układu dźwigniowego hamulca tarczowego, można je sklasyfikować następująco:

- modele do obliczeń kinematycznych,

- modele do obliczeń sił i momentów,

- modele do obliczeń częstotliwości drgań własnych elementów mechanizmu dźwigniowego.

W pracach $[1,2,4]$ do obliczeń wielkości kinematycznych tzn. przemieszczeń poszczególnych elementów układu dźwigniowego hamulca, zaproponowano model, którego schemat przedstawiono na rysunku 1.
The noise generated by motor vehicles is one of the negative factors affecting the deterioration of the environment (especially acoustic), where people are present. Vibroacoustic phenomena, especially those emitted by braking systems, are regarded as highly undesirable. The problem of vibration in the brakes, in both rail and road vehicles, was already noticed in the $30 \mathrm{~s}$ of the twentieth century [10]. At the beginning the researchers pointed out that the noise and vibration generated by the brake was due to the friction characteristics of the tribological pair, making the appearance of the effect was the result of the value of the friction coefficient changing along with the rotational speed. It was also claimed that the coefficient of static friction is greater than kinetic friction. The consequence of vibration in the brake in conjunction with the propagation of sound is the unstable work of the brake system manifested by a variable value of the instantaneous friction coefficient.

Described problems are the result of research conducted in the framework of a project funded by the National Centre for Research and Development (LIDER V program, No. LIDER/022/359/L5/13/NCBR/2014).

\section{Selected brake vibration models}

The basic components of a disc brake system includes the brake disc, which is rigidly connected to the wheel set, and the brake caliper with pad. Models with varying degrees of simplification are used for the calculation of the parameters of the disc brake leverage. Depending on the use of disc brake lever models, these models can be classified as:

- kinematic calculation models,

- force and torque calculation models,

- models for the calculation of the natural frequencies of the lever mechanism components.

In $[1,2,4]$ a model is proposed for the calculation of the kinematic values, i.e. the movements of the various elements of the brake leverage, which is as schematically shown in figure 1 . 


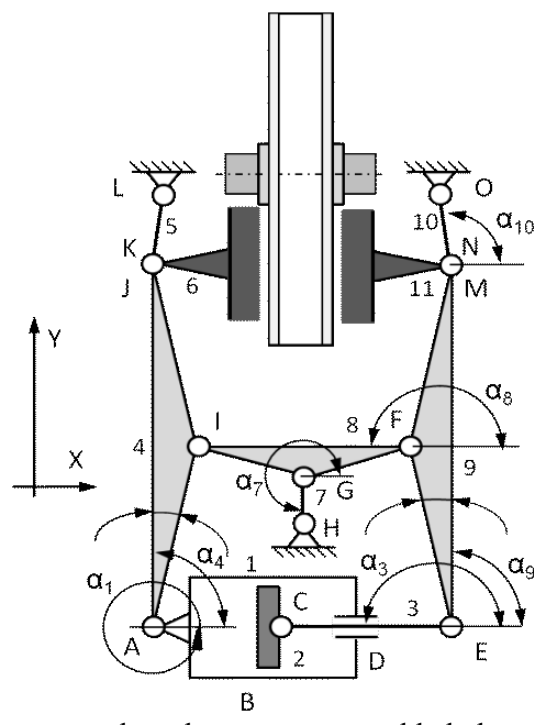

Rys. 1. Schemat strukturalny tarczowego układu hamulcowego [2]

$\mathrm{Na}$ schemacie strukturalnym przedstawionym na rysunku 1 oznaczone są człony nieruchome od 1 do 11 (liczba członów nieruchomych $\mathrm{n}_{\mathrm{r}}=11$ ) oraz pary kinematyczne od A do O (liczba par kinematycznych $\mathrm{p}$ $=15)$.

W ostatnim czasie często przywoływanym i rozwijanym modelem układu hamulcowego, co przedstawia rysunek 2, jest model zaprezentowany przez Rudolpha and Poppa [6, 7]. W roku 1972 North [5] opracowal szczególny model układu hamulcowego o ośmiu stopniach swobody.

Pierwsze modele zakładały, że drgania samowzbudne hamulca są związane ze spadkiem wspólczynnika tarcia i wzrostem prędkości poślizgu. Jest to słuszne dla wielu materiałów ciernych, jednak dla ograniczonego zakresu zmian prędkości. Jeżeli założy się model hamulca o jednym stopniu swobody zgodnie $\mathrm{z}$ rysunkiem 3 , to równanie ruchu przedstawia zależność (1.1) [10]. a)

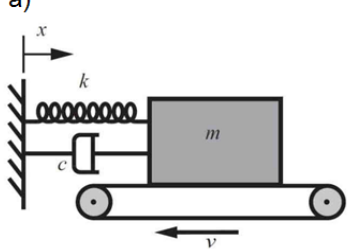

b)

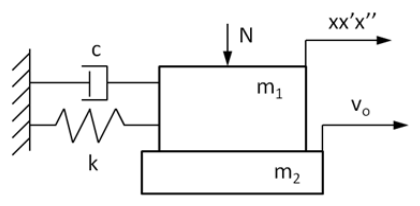

Rys. 3. Modele drgań: a) Model sprężystego układu ciernego [3, 10], b) Model układu mechanicznego ze sprzężeniem zwrotnym $\mathrm{m}_{1}$ i $\mathrm{m}_{2}$ - masy ciał, $\mathrm{N}$ - nacisk, $\mathrm{k}$ - współczynnik sprężystości, $\mathrm{c}$ współczynnik tłumienia wiskotycznego, $\mathrm{v}_{\mathrm{o}}$ - prędkość

Fig. 3. Vibration models: a) Model of an elastic friction system [3, 10], b) Model of a mechanical model with feedback $\mathrm{m}_{1}$ and $\mathrm{m}_{2}-$ masses, $\mathrm{N}$ - pushing force, $\mathrm{k}$ - elasticity coefficient, $\mathrm{c}$ - viscous damping coefficient, $\mathrm{v}_{\mathrm{o}}$ - speed

Układ opisany równaniem ruchu, będzie wpadał w niestabilne drgania w zależności od wartości współczynnika tłumienia, co przedstawia zależność (1.1).
The structural schematic shown in figure 1 identifies the elements that are fixed in place 1 to 11 (number of fixed elements $n_{r}=11$ ) and kinematic pairs from A to $O$ (number of kinematic pairs $p=15$ ).

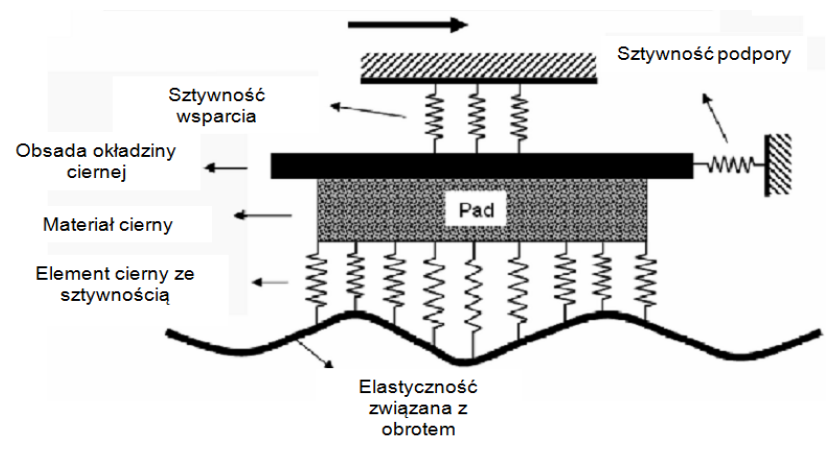

Rys. 2. Model sprężystego układu ciernego [12]

Fig. 2. Model of an elastic friction system [12]

The recently often cited and developed braking system model is the model presented by Rudolph and Poppa [6, 7], shown in figure 2. In 1972 North developed a special brake system model with eight degrees of freedom [5].

In the first models there was assumed that the selfoscillations of the brake are associated with a decrease in the friction coefficient and increase in slide speed. This is true for many friction materials, but only for a limited range of speed changes. If we assume brake model with one degree of freedom, as shown in figure 3 , then the equation of motion can be expressed with the equation (1.1) [10].

The arrangement described by this equation of motion will fall into unstable vibration depending on the value of the damping coefficient, as shown in equation (1.1).

$$
c>\frac{N \Delta \mu}{2 \Pi \sqrt{k m v_{o}^{2}}}
$$

The first model, which presents the possibility of friction braking system instability for a constant friction coefficient was presented by Spurr, as a slider on an angle bracket, as shown in figure 4. This solution has been enhanced by Jarvis and Earles. This model, however, is geometrically different from an real friction brake [10].

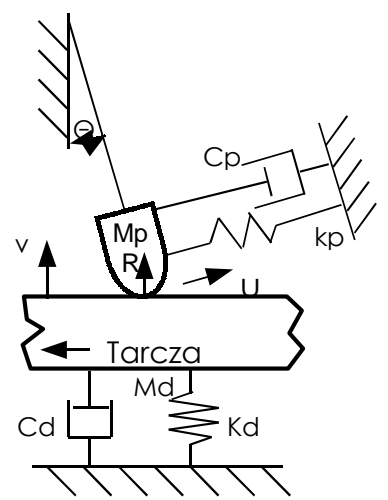

Rys. 4. Model układu ciernego tarcza-ślizgacz na wsporniku kątowym

Fig. 4. Friction system model of slider-disc on an angle bracket 


$$
c>\frac{N \Delta \mu}{2 \Pi \sqrt{k m v_{o}^{2}}}
$$

Pierwszym modelem, który przedstawia możliwość niestabilności układu ciernego dla stałej wartości współczynnika tarcia został przedstawiony przez Spurra, jako ślizgacz z kątowym wspornikiem, co przedstawia rysunek 4. Rozwiązanie to zostało udoskonalone przez Jarvisa i Earlesa. Model ten geometrycznie jednak odbiega od rzeczywistego hamulca ciernego [10].

Warunek niestabilności określony jest wzorem (1.2)

$$
\frac{1}{2}(\mu-\operatorname{tg} \Theta \sin ) 2 \Theta>\frac{C_{p}}{C_{d}}
$$

Kolejny model zaproponowany został przez Northa, a następnie Millnera. Był to model tzw. flattera binarnego, który jest bardziej zbliżony do hamulca tarczowego. Rysunek 5 przedstawia uproszczoną wersję modelu o dwóch stopniach swobody. Mechanizm drgań w tym wypadku podobny jest do tego, który towarzyszy trzepotaniu skrzydeł w samolotach, czyli flutterowi. Bieżnia hamulca tarczowego została zastąpiona przez sztywną prostą belkę o dwóch stopniach swobody. Przekrój układu okładzina-bieżniaokładzina o długości 21 przedstawia rysunek 5.

Warunek niestabilności przedstawionego modelu przedstawia zależność (1.3) [10]:

$$
\frac{8 M I N \cdot \mu^{2} h}{\left(I-\frac{1}{3} M l^{2}\right)^{2}}>K_{p}>0
$$

gdzie: $2 h \quad-\quad$ grubość belki,

$M \quad-$ masa,

$I \quad-$ inercja,

$2 l \quad-\quad$ długość belki,

$K p \quad-\quad$ sztywność poprzeczna okładzi-

$K_{p} I^{2} / 3 \quad-\quad$ ny, ka 21.

Jak wykazali Crolla i Lang, ten i inne modele nie w pełni odzwierciedlają rzeczywisty hamulec, jednak dzięki nim można otrzymać jakościową wskazówkę dla procesu projektowania i dla szukania rozwiązań konstrukcyjnych eliminujących niektóre klasy drgań hamulców i emitowanego przez nie hałasu [10].

Bardziej dokładną metodą w prognozowaniu drgań układu hamulcowego jest metoda elementów skończonych. Większa złożoność modeli nie przyniosła jednak rozwiązania w zrozumieniu mechanizmu drgań w hamulcach. Przyczyną tego jest ograniczenie modelowania z użyciem elementów skończonych do odizolowanych elementów niż wzajemnie powiązanych systemów.
The instability condition is described by the formula (1.2) [10]:

$$
\frac{1}{2}(\mu-\operatorname{tg} \Theta \sin ) 2 \Theta>\frac{C_{p}}{C_{d}}
$$

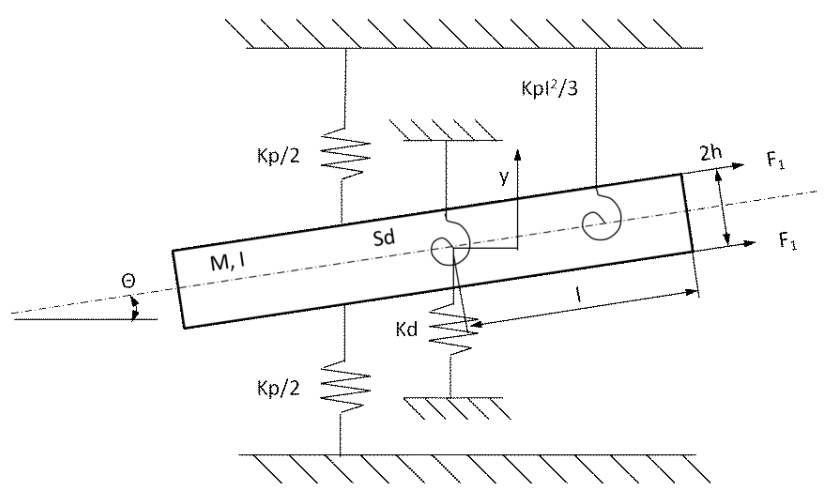

Rys. 5. Model flattera binarnego o parametrach skupionych [10]

Fig. 5. Model of a binary flutter with lumped parameters [10]

Another model has been proposed by North, and then Millner. It was the so-called binary flutter model, which is more closely related to the brake disc system. Figure 5 shows a simplified version of the model with two degrees of freedom. Vibration mechanism in this case is similar to that which accompanies fluttering in aircraft wings. The brake tread has been replaced with a straight rigid bar with two degrees of freedom. The cross-section of the lining-tread-lining system with a length of 21 is shown in figure 5 .

The instability condition of this model is described by the formula (1.3) [10]:

$$
\frac{8 M I N \cdot \mu^{2} h}{\left(I-\frac{1}{3} M l^{2}\right)^{2}}>K_{p}>0
$$

where: $2 h \quad-$ beam thickness,

$$
\begin{array}{lll}
M & - & \text { mass, } \\
I & - & \text { inertia, } \\
2 l & - & \text { beam length, } \\
K p & - & \text { lining torsional stiffness, } \\
K_{p} I^{2} / 3 & - & \text { rotational stiffness for the } 21 \\
& & \text { section. }
\end{array}
$$

As shown by Crolla and Lang, this and other models do not fully reflect an real brake, however, they can provide a qualitative guideline for the design process and help find structural solutions to eliminate some types of brake vibrations and the generated noise [10].

A more accurate method of predicting the vibration of the brake system is the finite element method. The increased complexity of the models has not brought a solution to understanding the mechanism of brake vibration. This is because the finite element modeling reduces the problem to a set of isolated elements rather than to interrelated systems. 


\section{Podział zjawisk wibroakustycznych}

Drgania $i$ hałas generowany przez układ hamulcowy zawiera się $\mathrm{w}$ bardzo szerokim paśmie częstotliwości tj. od częstotliwości poniżej zakresu słyszalności narządu słuchu człowieka, aż do zakresu ultradźwięków $[9,10]$. Ponadto drgania i hałas występujące w czasie hamowania również zależne są od danych warunków pracy, takich jak prędkość, temperatura lub wilgotność powietrza. W literaturze międzynarodowej zdefiniowano i podzielono procesy wibroakustyczne na moan (jęczenie), judder (trzęsienie, dudnienie) oraz squeal (pisk) co przedstawia rysunek 6 . Ze względu na skromną literaturę krajową w zakresie wibroakustyki układu hamulcowego, powszechne jest przedstawianie poszczególnych zjawisk wibroakustyczne stosując nazewnictwo angielskie.

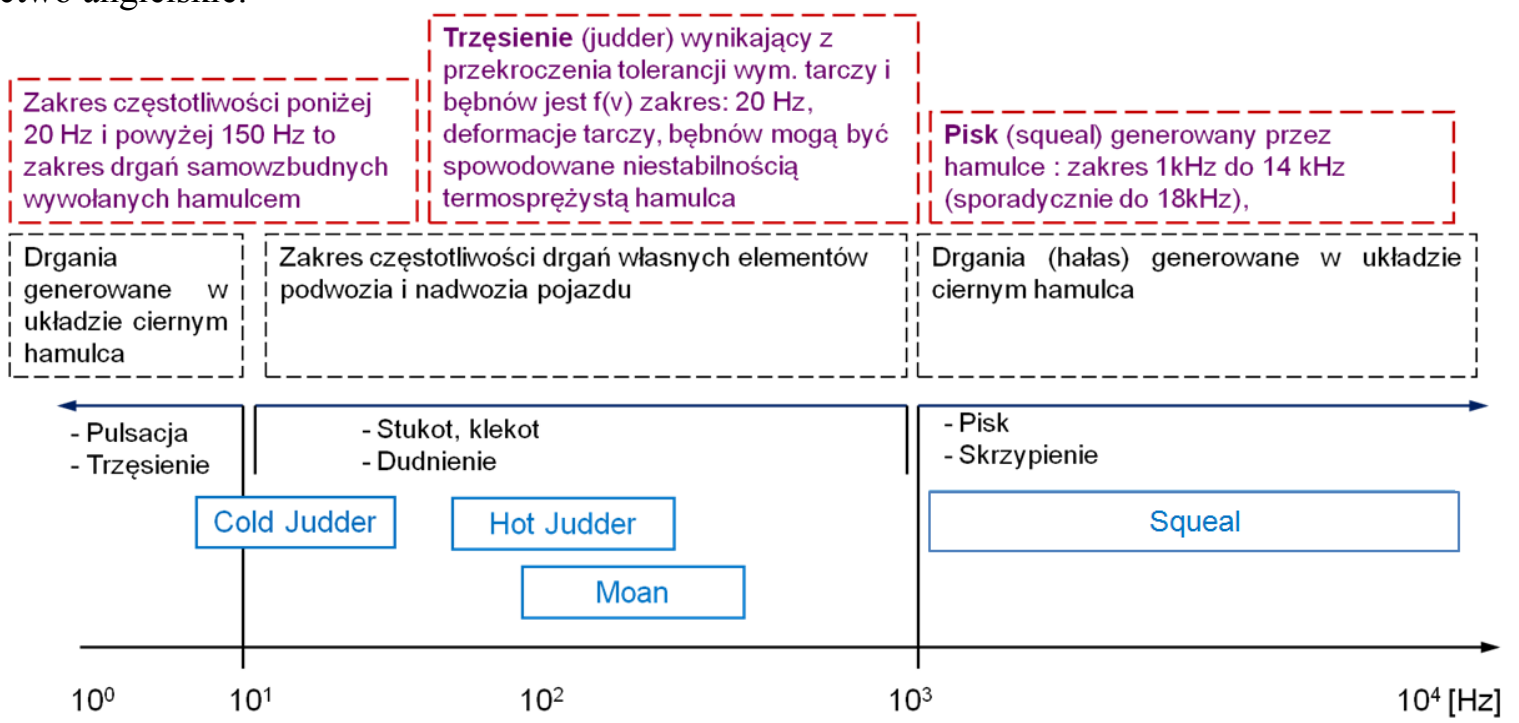

The brake-induced self-oscillation frequency range lies below $20 \mathrm{~Hz}$ and over $150 \mathrm{~Hz}$

Judder: resulting from exceeding the tolerance of the disc and drums is the $f(v)$ range: $20 \mathrm{~Hz}$, disc and drum deformations can be caused by the thermos-elastic instability of the brake

Squeal: generated by the brakes: range 1 to $14 \mathrm{kHz}$ (sporadically up to $18 \mathrm{kHz}$ )

Vibrations generated in the brake friction system

The resonant frequency range of the vehicle elements

Vibrations (noise) generated in the brake friction system.

Rys. 6. Podział zjawisk wibroakustycznych pochodzących od układu hamulcowego [9, 10]

Fig. 6 . The classification of vibroacoustic phenomena caused by the brake system $[9,10]$

\section{Badania poligonowe tarczowego układu hamul- cowego}

Badania przeprowadzone w warunkach eksploatacyjnych na wagonach kolejowych dowiodły występowanie zjawiska drgań samowzbudnych rezonansowych w ostatniej fazie hamowania również na wszystkich badanych okładzinach ciernych, charakteryzujących się różną grubością (zużyciem). W przeciwieństwie do badań stanowiskowych, wspomniane drgania wystapiły tylko na okładzinie zużytej do $15 \mathrm{~mm}$. W przypadku badań poligonowych na wszystkich badanych okładzinach drgania samowzbudne rezonansowe charakteryzowały się różną wartością amplitudy chwilowych przyspieszeń drgań. Na rysunku 7 przedstawiono przebiegi czasowe chwilowych przyspieszeń

\section{Disc brake system field tests}

Tests conducted in the operating conditions typical for railway carriages proved the occurrence of the selfexcited resonant oscillation phenomenon in the last phase of braking, and for all the tested friction linings, characterized by different thickness (wear). In contrast to the test bench, the mentioned vibrations occurred on a lining worn down to the thickness of $15 \mathrm{~mm}$. For tests done in the field the self-oscillation resonance was characterized by a different value of instantaneous amplitude of vibration acceleration for all tested linings. Figure 7 shows the waveforms of instantaneous vibration acceleration for the tested linings with the resonant vibrations occurring in the last phase of braking. 
drgań dla badanych okładzin z występującymi drganiami rezonansowymi w ostatniej fazie hamowania.

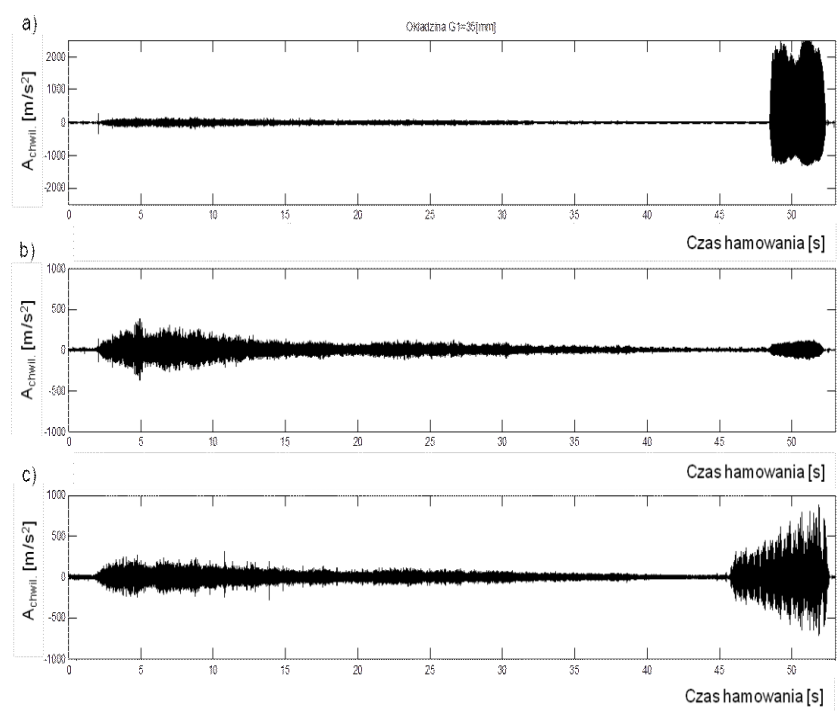

Rys. 7. Przebiegi czasowe chwilowych przyspieszeń drgań obsad z okładzinami o różnej grubości z widocznymi drganiami samowzbudnymi rezonansowymi

a) grubość okładziny $\mathrm{G} 1=35 \mathrm{~mm}, \mathrm{~b}$ ) grubość okładziny $\mathrm{G} 2=25$ $\mathrm{mm}, \mathrm{c})$ grubość okładziny $\mathrm{G} 3=15 \mathrm{~mm}$

Fig. 7. Vibration acceleration of caliper with pads of varying thickness as a function of time, with visible self-oscillation resonance

a) lining thickness G1 $=35 \mathrm{~mm}, \mathrm{~b}$ ) lining thickness $\mathrm{G} 2=25 \mathrm{~mm}, \mathrm{c}$ ) lining thickness $\mathrm{G} 3=15 \mathrm{~mm}$

Analizy częstotliwościowe hamowań na badanych okładzinach pozwalają określić częstotliwość drgań, przy której zjawisko drgan samowzbudnych o charakterze rezonansowych występuje. Widma drgań z hamowań, przy których wystapiły drgania rezonansowe, względem drgań $z$ hamowania przy tych samych nastawach bez wspomnianego zjawiska przedstawiają rysunki 8 i 9.

Testy impulsowe przeprowadzone na elementach tarczowego układu hamulcowego wykazały, że przy 6 $\mathrm{kHz}$ znajdują się częstotliwości drgań rezonansowych tarczy i obsady hamulcowej, co również potwierdziły badania stanowiskowe [8].

\section{Podsumowanie}

Przedstawione rodzaje modeli stosowanych w badaniach dotyczących hamulców tarczowych odnoszą się do różnorodnych zjawisk zachodzących w czasie hamowania. Nie wyczerpują one jednak możliwości stosowania procesu modelowania do obliczeń parametrów opisujących procesy zachodzące $\mathrm{w}$ parze ciernej związanych ze zjawiskiem tarcia, jak również zjawisk generowanych przez złożony obiekt techniczny, jakim niewątpliwie jest para cierna razem $\mathrm{z}$ mechanizmem dźwigniowym, a także jej wpływ na otoczenie.

Podczas studiowania problemu modelowania w obliczeniach hamulców w szczególności dla hamulca tarczowego nie stwierdzono prób zbudowania modelu

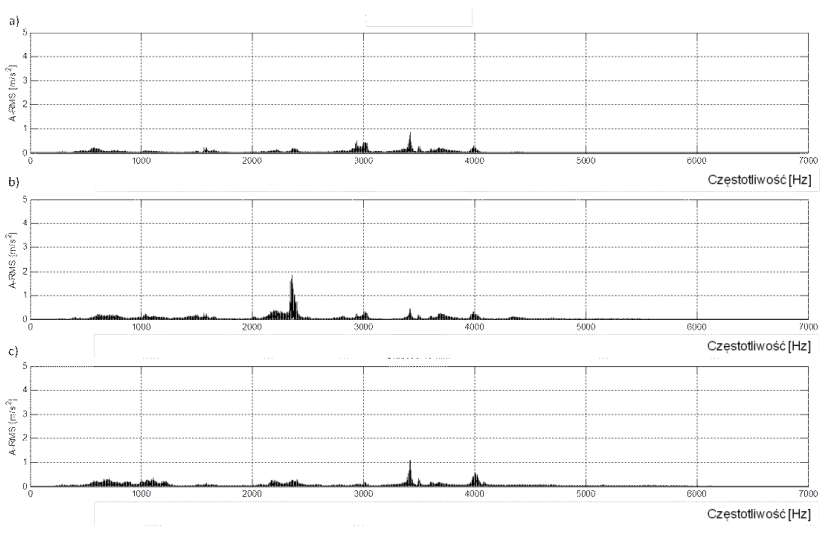

Rys. 8. Zależność amplitudy przyspieszeń drgań od częstotliwości dla różnych grubości okładziny przy hamowaniu zatrzymującym; w czasie badań poligonowych brak drgań samowzbudnych rezonansowych

a) grubość okładziny $\mathrm{G} 1=35 \mathrm{~mm}$, b) grubość okładziny G2=25 $\mathrm{mm}, \mathrm{c})$ grubość okładziny G3=15 mm

Fig. 8. The relations between the amplitude of the vibration acceleration and the frequency for various thicknesses of the pad when braking; with no self-oscillation resonance occurring in the field tests

a)pad thickness $\mathrm{G} 1=35 \mathrm{~mm}, \mathrm{~b}$ ) pad thickness $\mathrm{G} 2=25 \mathrm{~mm}$, c) pad thickness $\mathrm{G} 3=15 \mathrm{~mm}$

Frequency analysis of braking with the tested linings allow determining the oscillation frequency at which the phenomenon of self-oscillation resonance occurs. Vibration spectrum of braking, at which the resonance vibration occurred, are compared to the vibration of the brake at the same settings but without the phenomenon is presented in figures 8 and 9.

Impulse tests carried out on the elements of the disc brake systems have shown that the frequency of resonance vibrations of the brake disc and the stocking are at $6 \mathrm{kHz}$, which was also confirmed by stationary tests [8].

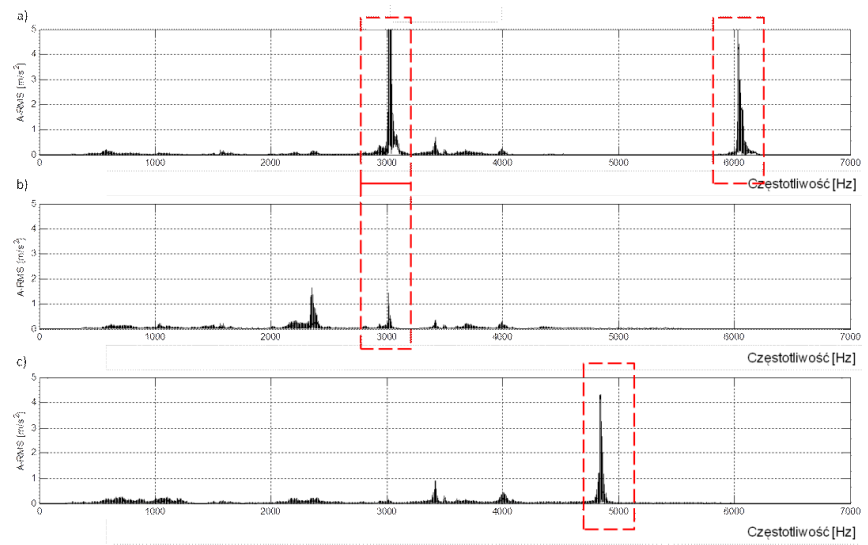

Rys. 9. Zależność amplitudy przyspieszeń drgań od częstotliwości dla różnych grubości okładziny przy hamowaniu zatrzymującym w czasie badań poligonowych z drganiami samowzbudnymi rezonansowymi

a) grubość okładziny G1=35 mm, b) grubość okładziny G2=25 $\mathrm{mm}, \mathrm{c})$ grubość okładziny $\mathrm{G} 3=15 \mathrm{~mm}$

Fig. 9. The relations between the amplitude of the vibration acceleration and the frequency for various thicknesses of the pad when braking; with self-oscillation resonance occurring in the field tests a) pad thickness $\mathrm{G} 1=35 \mathrm{~mm}, \mathrm{~b}$ ) pad thickness $\mathrm{G} 2=25 \mathrm{~mm}, \mathrm{c}$ ) pad thickness $\mathrm{G} 3=15 \mathrm{~mm}$ 
dynamicznego zespołu obsada-okładzina-tarcza hamulcowa, gdzie zamiast sztywnych elementów (okładzina, tarcza hamulcowa) można zastosować elementy sprężysto-thumiące. Model taki umożliwiłby np. oszacowanie rzeczywistych sił działających na elementy układu dźwigniowego, w szczególności sworznie łączące obsady hamulcowe $\mathrm{z}$ dźwignią główną prawą $\mathrm{i}$ lewą bez konieczności stosowania zaawansowanych technik komputerowych takich jak MES.

W przypadku modeli dotyczących obliczeń pary ciernej stwierdzono, że nie można przy ich pomocy opisać zjawiska propagacji drgań w elementach układu dźwigniowego hamulca generowanych przez elementy pary ciernej w czasie hamowania. Znajomość transmitancji oraz modelu propagacji drgań w hamulcu tarczowym jest niezbędna do zbudowania systemu diagnostycznego, którego struktura zawiera model, dzięki któremu można zadawać niezdatności układu i porównywać symptomy generowane przez obiekt rzeczywisty z symptomami określającymi stany wygenerowane przez model. Dlatego cały czas trwaja prace $\mathrm{w}$ celu opracowania modelu oddziaływań dynamicznych w hamulcu tarczowym, umożliwiajacego symulację zużycia eksploatacyjnego jego elementów, co $\mathrm{w}$ konsekwencji wpływa na proces hamowania rozumianego zmiennym przebiegiem chwilowego współczynnika tarcia.

\section{Streszczenie}

W pojazdach szynowych ze względu na coraz to większe prędkości jazdy prowadzi się prace nad udoskonalaniem ukladów hamulcowych tak, aby zatrzymanie pojazdu odbyto się na możliwie najkrótszej drodze hamowania. Niestabilność pracy wynika między innymi $z$ występowania drgań na styku elementów ciernych, co wplywa na obniżenie sprawności procesu hamowania. W praktyce oznacza to, że podczas hamowania pojazdów występujacy zmienny $w$ czasie opór tarcia może być powodem nierównomiernego przebiegu procesu hamowania. Skutki tych zmian mogq objawić sie w postaci drgań samowzbudnych.

Celem artykułu jest przedstawienie wybranych modeli opisujacych drgania hamulców oraz wyników badań wibroakustycznych tarczowego uktadu hamulcowego wagonu pasażerskiego.

\section{LITERATURA}

[1] Kaluba M., Zużycie okładzin ciernych hamulca tarczowego pojazdów szynowych, Pojazdy Szynowe 1999 nr 4, s. 24-29.

[2] Kadziołka T., Kowalski S, Smolarski D., Analiza porównawcza wrażliwości dźwigniowych hamulców kolejowych, Pojazdy szynowe nr 1/2011.

\section{Conclusions}

The presented models used in studies of disc brakes relate to a variety of phenomena occurring during braking. However, they do not exhaust the possibilities of using process modeling to calculate the parameters that describe the processes occurring in the friction pair associated with the phenomenon of friction, as well as phenomena generated by a complex technical object, which the friction pair together with the lever mechanism undoubtedly is, and its impact on the environment.

While studying the problem of brake system modeling for calculations, in particular for a disc brake, no attempt was made to build a dynamic model of shoelining-disc, where instead of rigid elements (lining, brake disc) elastic-damping elements can be used. Such a model would enable, for example, the estimation of the actual forces acting on the leverage, in particular the pins connecting the brake calipers with the right and left main lever without having to use advanced computing techniques such as FEM.

In the case of models used for the calculations relating to the friction pair it was found that they cannot be used to describe the phenomenon of vibration propagation in the brake leverage components that is generated by the friction pair during braking. The knowledge of the transmittance and a model of vibration propagation in the disc brake is essential to build a diagnostic system, whose structure includes a model with which it is possible to simulate problems in the system and compare the symptoms generated by the real object to the symptoms defining the conditions generated by the model. This is why efforts continue to be made in an attempt to develop a model of the dynamic interactions present in a disc brake, enabling the simulation of wear and tear of its components, which influences the braking process with changing in the instantaneous friction coefficient.

\section{Summary}

Attempt to raise train speed involves application of greater braking power i.e. braking systems rapidly absorbing and dispersing stored heat energy-Work instability arises from the occurrence of vibrations on friction element, which affects the lower efficiency of the braking process. In practice, this means that, during braking the vehicles currently alternative at a time of friction resistance may cause uneven braking process. The effects of these changes can manifest in the form of vibrations the high amplitude of the input. The vibrations generated by the assemblies are moved per vehicle, which also adversely affects ride comfort.

The purpose of this article is to present selected models to describe the vibrations of the brakes and the test results of research vibration of the disc brake system of the braking passenger car. 
[3] Kinkaid N.M., O'Reilly O. M, Papadopoulos P., Automotive disc brake squeal. Journal of sound and vibration 267 (2003) 105-166. Department of Mechanical Engineering, University of California, Berkeley, USA.

[4] Nowicki J., Obliczenia symulacyjne skuteczności hamowania pociagu, XIV Konferencja Naukowa POJAZDY SZYNOWE 2000, Kraków, Arkanów, 9-13 październik 2000, t. 2, s. 139-146.

[5] North M.R, Disc brake squeal-a theoretical model, Technical Report 1972/5, Motor Industry Research Association, Warwickshire, England, 1972.

[6] Rudolph M., Popp K., Brake squeal, in: K. Popp (Ed.), Detection, Utilization and Avoidance of Nonlinear Dynamical Effects in Engineering Applications: Final Report of a Joint Research Project Sponsored by the German Federal Ministry of Education and Research, Shaker, Aachen, 2001, pp. 197225.

[7] Rudolph M., Popp K., Friction induced brake vibrations, in: CD-ROM Proceedings of DETC'01, DETC2001/VIB-21509, ASME, Pittsburgh, PA, 2001, pp. 1-10.

[8] Sawczuk W., Szymański G. Zastosowanie testów impulsowych do oszacowania częstotliwości rezonansowych wybranych elementów kolejowego układu hamulcowego, Logistyka 6/2014.

[9] http://www.motofaktor.pl/47,2/WARSZTAT-24-7/Zeby-klocki-hamulcowe-nie-piszczaly,2643.html; (30.04.2015)

[10] Ścieszka S.F., Hamulce cierne. Zagadnienia materiałowe, konstrukcyjne i tribologiczne, Wydawnictwo Gliwice-Radom 1998, s.15.

[11] Thompson J. K.,: Brake NVH. Testing and Measurements. SAE International.

[12] Triches Junior M., Samir N. Y. Gerges, Jordan R., Analysis of brake squeal noise using finite element method: A parametric study, Federal University of Santa. 